\title{
THE DRIVE FOR MUSCULARITY AMONG ADOLESCENT BOYS: ITS RELATIONSHIP WITH GLOBAL SELF-ESTEEM
}

\author{
Rasa Jankauskienė, Ramutis Kairaitis \\ Lithuanian Academy of Physical Education, Kaunas, Lithuania
}

Rasa Jankauskienè. Doctor of Social Sciences (Educational Science). Head of the Department of Combat Sports at the Lithuanian Academy of Physical Education. Research interests - body image of persons involved in recreational and achievement sport, prevalence of physical activity.

\begin{abstract}
Among adolescent boys a higher drive for muscularity is related with poorer self-esteem and more symptoms of depression. There is an agreement that male athletes, in general, experience greater body satisfaction compared to nonathletes of the same age, however there is lack of studies to demonstrate how participation in various sports relates in terms of drive for muscularity and global self-esteem among adolescent boys. One hundred adolescent boys (mean age $-14.63 \pm 1.97)$ took part in the study. 29 boys were at $6^{\text {th }}$ grade, $34-$ at $8^{\text {th }}$, and 37 - at $10^{\text {th }}$ grade. All the participants completed the self-constructed questionnaire consisting of 21 items. The following blocks of questions or statements were included into the questionnaire: demographic variables (age, grade, the living place (urban or rural)), global self-esteem (Rosenberg's (1989) questionnaire of self-esteem), body esteem (the satisfaction with one's own appearance and appearance of various body parts), and involvement to after-school activities (involvement in activity (for at least half a year) was considered as formal belonging to a club, school, or group, but not independent activities at the leisure time). The participants also completed the questionnaire Drive for Muscularity Scale (DMS) (McCreary, Sasse, 2000). Results showed no significant differences in the drive for muscularity among the boys involved in different after-school activities, while the greatest drive was demonstrated by adolescents involved in dancing. The adolescents involved and not involved in sport did not show significant differences in global self-esteem and overall appearance evaluation while the lowest dissatisfaction was common to the boys involved in dancing. The drive for muscularity was not significantly related to poorer overall appearance evaluation and self-esteem among adolescent boys involved in various after-school activities. Involvement in sport activities might mediate the negative effect of the drive for muscularity. The drive for muscularity might also be closely related to the demands of sport activities, but not to the improvement of personal appearance. However, it was found that dissatisfaction with body image and weight was more closely related to low self-esteem among girls, but not among boys, so our study partially supported the previous findings. The future studies should investigate the drive for muscularity, body-esteem and self-esteem interrelation in the samples of adolescent boys involved in recreational and professional sport.
\end{abstract}

Keywords: adolescent boys, drive for muscularity, self-esteem, afterschool activities.

\section{INTRODUCTION}

$\mathrm{W}$ estern cultures are blamed for emphasizing physical beauty. Despite the fact that body appearance is mainly an object of women's concerns, there are many signs that dissatisfaction with one's own body among boys and men makes them suffer. Many men are motivated to achieve the prowess and "physicality" that have become the essential ingredient of male attractiveness. Research has suggested that people assume muscular men to be more mascu- line (McCreary et al., 2005). Some researchers argue that "men are susceptible to a greater variety of weight concerns than females because the ideal to which men aspire is much more complex than thinness norm women embrace" (Corson, Andersen, 2002). As feminism has changed females' perceptions of themselves and their socially constructed gender roles, the perceptions of maleness have also changed. Women are achieving more social power and independence, so they can be 
more selective in the mates they choose, which is why muscularity might be an attempt to preserve the traditional notion of the male role (Olivardia, 2002). The studies demonstrate that the commercial value of men's body has increased over the past twenty years (Pope et al., 2001).

Some authors (Pope et al., 2000) point out that the modern generation's obsession with fitness and appearance is the concept of the "supermale" which has infected millions of young men with an "Adonis complex" (V-shaped muscular body as the Greek half - man, half — god Adonis represented). Seeking for "appearance success" is related to the increase of eating disorders, compulsive exercising, appearance obsession, use of not prescribed pharmaceuticals and finally with muscular or body dysmorphia. There is abundance of studies giving reliable empirical evidence on the topic (McCreary, Sasse, 2000; Cohane, Pope, 2001; Pedersen, Wichstrom, 2001; Choi et al., 2002; Raudenbush, Meyer, 2003).

The studies show that dissatisfaction with body image is common among adolescent boys in Western cultures (Furnham et al., 2002). Adolescence is an important period for the development of body image, because a number of normative developmental challenges influence body image, including pubertal development, gender role intensification. It is believed that this transition is more stressful for girls, while some researchers do believe opposite because of the complexity of the development of male body image. Studies show that the ideal male body must be muscular and lean enough at the same time (Raudenbush, Meyer, 2003).

In industrialized countries, body image and overall physical appearance is one of the most important predictors of adolescents' global selfesteem (McCreary, Sasse, 2000). However, some sports and forms do encourage preoccupation with a body shape, especially among adolescent girls. Males involved in sports emphasizing bulk, power, and muscular definition may also be susceptible to negative body image, because the perceptual discrepancy between their ideal (hypermuscular ideal featured in movies, bodybuilding and wrestling) and actual body image.

The conception "drive for muscularity" is used trying to explain an individual's perception of his / her muscularity and conviction that bulk should be added to his or her body frame, in the form of muscle mass (irrespective of a person's percentage of actual muscle mass or body fat) (McCreary, Sasse, 2000). Among adolescent boys a higher drive for muscularity is related with poorer self-esteem and more symptoms of depression compared to girls (McCreary, Sasse, 2000). It is widely agreed that male athletes in general experience greater body satisfaction, especially football players and body-builders compared to nonathletes of the same age, however there are not many studies demonstrating how participation in various sports and after-school activities are related to the drive for muscularity and global self-esteem among adolescent boys. The aim of this study was to test the associations between the drive for muscularity and global self-esteem in adolescent boys involved in various after-school activities.

\section{PARTICIPANTS, INSTRUMENT AND PROCEDURE}

Research participants were students from the sixth, eighth, and tenth grades of Jurbarkas secondary schools. The sample contained 110 students from four secondary schools. 10 questionnaires were not filled in fully or were damaged, and therefore they were rejected. Consequently, the questionnaires of 100 boys aged between 11 and 17 years, mean (SD) 14.63 (1.97) were analyzed. 29 boys were in the $6^{\text {th }}$ grade, $34-$ in the $8^{\text {th }}$, and 37 - in the $10^{\text {th }}$ grade. All the participants completed the self- constructed questionnaire consisting of 21 items. The following blocks of questions or statements were included into the questionnaire: demographic variables (age, grade, the living place (urban or rural)), global self-esteem (M. Rosenberg's (1989) questionnaire of selfesteem), body esteem (the satisfaction with one's own appearance and the appearance of different parts of the body), and involvement in after-school activities (involvement in an activity (for at least half a year) meant formal belonging to a club, school or group, but not independent activities at the leisure time). Besides participants completed the Drive for Muscularity Scale (DMS) (McCreary, Sasse, 2000). The DMS is a 15 -item measure of the extent to which people desire to have a more muscular body. Higher scores reflect a greater drive for muscularity. The scale showed high internal consistency in this sample (Cronbach's alpha was 0.8 ). The questionnaires were filled in during the classes upon prior agreement with teachers. The procedure was carried out by the 
researchers themselves. Participation of students was based on the principles of anonymity and good will. The pupils were given as much time as they needed. It took about 20 minutes on the average to fill in the questionnaire. The filled ones were collected at once.

Data Analysis. The data were analysed using the statistical package software system SPSS13.0. Bivariate associations were calculated using chisquare $\left(\chi^{2}\right)$ criterion $(\alpha=0.05)$. A one-way analysis of variance (one way ANOVA) was used to test the equality of means.

\section{RESULTS}

72 adolescents lived in urban places. $28 \%$ of the sample were not involved in some after-school activities. $35 \%$ of the boys were involved in sport games, $9 \%$ of them went in for combat sports, $11 \%$ - power sports (bodybuilding, weightlifting), $6 \%$ - dancing, $11 \%$ of boys were devoted to music and arts. The involvement in various after-school activities in each grade is presented in Table 1. The involvement in after-school activities decreased in every other grade, though the most distinct decrease was observed in involvement in dancing, music and arts $\left(\chi^{2}=16.6 ; \mathrm{df}=10\right.$; $\mathrm{p}=0.08)$.

One-way ANOVA test showed that there were no statistically significant differences in global self-esteem among adolescents who were and were not involved in sports, respectively - 19 (3.6) versus 19.07 (3.6). There were no statistically significant differences in the global selfesteem among adolescents involved and not involved in different after-school activities (mean (SD) -18.78 (3.86), range 7-28), $\mathrm{F}=0.84$; $\mathrm{df}=5, \mathrm{p}=0.52$, though the lowest mean of the global self-esteem was typical of adolescent boys involved in music and arts and the highest - for those involved in power sports (Table 2). There were no differences in global self-esteem between adolescents living in urban and rural places and learning in different grades.

$23 \%$ of adolescent boys evaluated their weight as too low, while $12 \%$ of the sample judged their weight as too high. $42 \%$ of boys reported dissatisfaction with their overall body appearance. The dissatisfaction with body appearance strongly depended on the evaluation of the body weight: the highest dissatisfaction was expressed by those adolescents who judged their weight as too

\begin{tabular}{|c|c|c|c|c|c|c|c|c|}
\hline & $\begin{array}{l}\text { Not } \\
\text { involved }\end{array}$ & $\begin{array}{l}\text { Sports } \\
\text { games }\end{array}$ & $\begin{array}{l}\text { Combat } \\
\text { sports }\end{array}$ & $\begin{array}{l}\text { Power } \\
\text { sports }\end{array}$ & Dancing & $\begin{array}{l}\text { Music and } \\
\text { arts }\end{array}$ & Total & \multirow{2}{*}{$\begin{array}{l}\text { Table } 1 \text {. The distribution of } \\
\text { adolescent boys involved in } \\
\text { various after-school activities } \\
\text { by grade }\end{array}$} \\
\hline $6^{\text {th }}$ grade & $8(28.6)$ & 4 (11.4) & $5(55.6)$ & $3(27.3)$ & $3(50)$ & $6(54.5)$ & $29(29)$ & \\
\hline $8^{\text {th }}$ grade & 8 (28.6) & 15 (42.9) & $1(11.1)$ & $4(36.4)$ & $3(50)$ & $3(27.3)$ & $34(34)$ & \multirow{2}{*}{$\begin{array}{l}\text { Note. In parenthesis - percen- } \\
\text { tage distribution of students in } \\
\text { sample. }\end{array}$} \\
\hline $10^{\text {th }}$ grade & $12(42.9)$ & $16(45.7)$ & $3(33.3)$ & $4(36.4)$ & 0 & $2(18.2)$ & 37 (37) & \\
\hline
\end{tabular}

\begin{tabular}{|l|l|l|l|l|l|l|}
\hline & $\begin{array}{l}\text { Not } \\
\text { involved }\end{array}$ & $\begin{array}{l}\text { Sports } \\
\text { games }\end{array}$ & $\begin{array}{l}\text { Combat } \\
\text { sports }\end{array}$ & Power sports & Dancing & $\begin{array}{l}\text { Music and } \\
\text { arts }\end{array}$ \\
\hline Mean (SD) & $19.07(3.57)$ & $18.66(3.54)$ & $18.89(4.40)$ & $20.18(3.43)$ & $18.83(3.37)$ & $16.91(5.61)$ \\
\hline
\end{tabular}

\begin{tabular}{|l|l|l|l|l|l|l|l|}
\hline & $\begin{array}{l}\text { Not } \\
\text { involved }\end{array}$ & $\begin{array}{l}\text { Sports } \\
\text { games }\end{array}$ & $\begin{array}{l}\text { Combat } \\
\text { sports }\end{array}$ & $\begin{array}{l}\text { Power } \\
\text { sports }\end{array}$ & Dancing & $\begin{array}{l}\text { Music and } \\
\text { arts }\end{array}$ & Total \\
\hline Dissatisfied & $17(60.7)$ & $15(42.9)$ & $3(33.3)$ & $4(36.4)$ & 0 & $3(27.3)$ & $42(42)$ \\
\hline
\end{tabular}

\begin{tabular}{|l|l|l|l|l|l|l|}
\hline & $\begin{array}{l}\text { Not } \\
\text { involved }\end{array}$ & $\begin{array}{l}\text { Sports } \\
\text { games }\end{array}$ & $\begin{array}{l}\text { Combat } \\
\text { sports }\end{array}$ & $\begin{array}{l}\text { Power } \\
\text { sports }\end{array}$ & Dancing & $\begin{array}{l}\text { Music and } \\
\text { arts }\end{array}$ \\
\hline Drive & $43.3(12.2)$ & $42.3(16.2)$ & $40.5(10.3)$ & $44.7(16.4)$ & $52.8(24.9)$ & $36.2(13.8)$ \\
\hline $\begin{array}{l}\text { Muscular dissatis- } \\
\text { faction }\end{array}$ & $26.6(7.8)$ & $24.9(8.9)$ & $24.7(6.4)$ & $26.5(9.4)$ & $26.8(12.2)$ & $21.8(10.5)$ \\
\hline $\begin{array}{l}\text { Behavior for muscle } \\
\text { increase }\end{array}$ & $15.4(5.5)$ & $15.9(7.5)$ & $14.9(4.6)$ & $16.3(6.6)$ & $22.8(11.6)$ & $13.3(4.3)$ \\
\hline
\end{tabular}

Table 2. The distribution of global self-esteem mean among groups involved and not involved in various afterschool activitie
Table 3. The distribution of dissatisfaction with overall bodily appearance among adolescent boys by involvement in after-school activities Note. In parenthesis - percentage of students in the sample.

Table 4. The mean (SD) distribution of the drive for muscularity in adolescent boys by involvement in after-school activities 
high and too low compared to the adolescents who evaluated their weight as normal, respectively: 9 (75\%) and $15(65.2 \%)$ versus $18(27.7 \%)$, $\left.\chi^{2}=15.9 ; \mathrm{df}=2 ; \mathrm{p}<0.01\right)$. It is worth noting that the evaluation of the overall bodily appearance did not depend on the grade, but it depended on the involvement in sports: adolescent boys involved in sports activities were significantly more satisfied with their overall body appearance: $39(63.9 \%)$ versus $11(39.3 \%), \chi^{2}=4.7$; $\mathrm{df}=1 ; \mathrm{p}<0.05$. Adolescent boys involved in dancing expressed the lowest dissatisfaction with their overall body appearance, $\chi^{2}=9.8 ; \mathrm{df}=5 ; \mathrm{p}=0.08$ (Table 3 ).

One-way ANOVA showed that there were no statistically significant differences in the global self-esteem among groups of adolescents evaluating their own body weight in different ways, while the lowest scores of global self-esteem were given by the adolescent boys who thought that their body weight was too low compared to those who judged their weight as normal or too high, respectively (mean (SD)): 17.9 (3.97) versus 19.1 (3.77) and 18.6 (4.25). The same tendency was observed comparing the groups of different body appearance evaluation: the greater dissatisfaction was related to the lower global self-esteem, respectively - 18.2 (4.0) and 19.2 (3.69).

The drive for muscularity increased with the grade, accordingly $41.4(14.6)$ in $6^{\text {th }}$ grade, 41.7 (17.6) in $8^{\text {th }}$ grade, and $44.5(13.2)$ in the $10^{\text {th }}$ grade, $\mathrm{F}=0.43, \mathrm{df}=2 ; \mathrm{p}=0.65$. It was higher among adolescents living in urban places compared to rural, respectively: 44.3 (15.5) versus 38.4 (13.4), $\mathrm{F}=3.1 ; \mathrm{df}=1, \mathrm{p}=0.08$. The lowest drive for muscularity was demonstrated by the boys who evaluated their weight as too high compared to those who thought that their weight was normal or too low, respectively: 35.2 (10.4) versus 43.9 (15.7) and 43.04 (14.8), $\mathrm{F}=4.73 ; \mathrm{df}=2$; $\mathrm{p}=0.2$.

There was no significant relationship between the drive for muscularity and the overall body appearance evaluation, but the boys who evaluated their appearance higher, scored lower on the drive for muscularity scale, respectively: 41.1 (14.9) versus 44.7 (15.3), $\mathrm{F}=1.43$; $\mathrm{df}=1, \mathrm{p}=0.23$. There was no significant relationship between the drive for muscularity and the self-esteem as well.

No significant differences were found between the drive for muscularity among adolescent boys involved and not involved in sport, respectively:
43.5 (16.4) versus 43.3 (12.2). It is interesting to note that, though the higher drive for muscularity was more common among the boys involved in power sports, the highest muscular drive was demonstrated by the adolescents involved in dancing, and the lowest - among those involved in music and arts (Table 4). The range was $15-90$ in this sample, mean (SD) - 42.6 (15.1). Adolescents living in urban places demonstrated higher drive for muscularity compared to those living in rural places, respectively: 44.3 (15.5) versus 38.4 (13.4), $\mathrm{F}=3.1$; $\mathrm{df}=1 ; \mathrm{p}=0.08$. The mean distribution of the dissatisfaction with the muscle mass (mean on the scale - 25.3 (8.78), range - 7-42) demonstrated that the lowest dissatisfaction was common to adolescent boys involved in music and arts activities $(\mathrm{F}=0.56$; $\mathrm{df}=5 ; \mathrm{p}=0.73$ ). The highest scores in behavior scale were demonstrated by the boys involved in dancing, while the lowest - by those involved in music and arts $(\mathrm{F}=1.7 ; \mathrm{df}=5 ; \mathrm{p}=0.14)$.

\section{DISCUSSION}

The aim of this observational study was to determine the relationship between the drive for muscularity and global self-esteem in adolescent boys involved in various after-school activities. While other studies show that the higher drive for muscularity relates with the poorer global selfesteem (McCreary, Sasse, 2000), our study shows the opposite: the higher drive for muscularity is related to the higher body and global self-esteem among adolescent boys involved in sport. Some studies (Koivula, 1999; Puniskiene, Laskiene, 2006) have shown that individuals who participate in sports have higher self-esteem than nonparticipants, however other researchers (Marsh, Jackson, 1986; Richman, Shaffer, 2000) have reported a weak link between sports participation and global self-esteem. Other studies (Bowker et al., 2003) emphasize that global self-esteem depends on gender role orientation and that highly feminine individuals benefit from recreational and noncompetitive sports activities and the opposite.

Involvement in sport activities might mediate the negative effect of the drive for muscularity. The drive for muscularity might also be closely related to the demands of sport activities, but not to the personal appearance improvement. However, it was found that dissatisfaction with body image and weight was more closely related to low 
self-esteem for girls, but not for boys (Furnham et al., 2002), so our study partially supported the previous findings. The future studies should investigate the drive for muscularity, body-esteem and self-esteem interrelation in the samples of adolescent boys involved in recreational and professional sport.

As we have expected the lowest drive for muscularity was demonstrated by boys involved in music and arts, though the highest drive for muscularity was demonstrated by adolescent boys involved in dancing activities. We were surprised to find that because dancing as an activity is traditionally attributed to the feminine activities in Western societies. The results might be explained by the notion that dancing as aesthetical activity requires emphasizing their appearance from its participants (males), so the participants (adolescents in this study) strive for the traditionally accepted male body image. The other explanation might be that men' participation in traditionally feminine activities forces them to preserve their traditional muscular body image.

The results of our study replicate the other findings (Furnham et al., 2002; Sweeting, West, 2002), which concluded that men's satisfaction with their body weight differs - some of them want to increase their body mass, while the significant majority wants to decrease it. The highest dissatisfaction with the global appearance was demonstrated by those boys who judged their weight as too low and too high. The tendency was noticed that evaluation of body mass as too low was related to the poorer global self-esteem. Interestingly enough, evaluation of body mass as too low, but not the drive for muscularity was related to poorer global self-esteem in our study.

While the drive for muscularity was not related to the poorer global self-esteem in this sample, the health educators should pay attention to the self-esteem of boys involved in music and arts activities. The lowest scores of their global selfesteem might be explained by the global change in the values occuring after the independence of Lithuania, when the most fashionable image of the men was related to the aggressive behavior and appearance. In the terms of body image, boys involved in sports, especially power and combat sports, have and advantage compared to those involved in delicate activities, because sport still plays a key role in the construction of "popular" masculinity for boys (Robertson, 2003). Poor selfesteem might have a life-long lasting effect on the psychosocial health (Mann et al., 2004).

The main limitation of this study is the slender sample, so the results should be verified in more numerous samples. The cross-sectional nature of the study does not let us make cause relationships, so other studies on this topic should have other designs (e. g. prospective) to clarify the effect of participation in various sports on the relationship between the drive for muscularity and the global self esteem.

\section{REFERENCES}

Choi, P. Y. L., Pope, Jr., H. G., Olivardia, R., Cash, T. F. (2002). Muscle dysmorphia: A new syndrome in weightlifters. British Journal of Sports Medicine, 36, 375377.

Cohane, G. H, Pope, Jr., H. G. (2001). Body image in boys: a review of the literature. International Journal of Eating Disorders, Vol. 29, 373-379.

Corson, P. W., Andersen, A. E. (2002). Body image issues among boys. In T. F. Cash, T. Pruzinsky (Eds.), Body image: A Handbook of Theory, Research and Clinical Practice (pp. 192-199). New York, London: The Guilford Press.

Bowker, A., Gadboys, S., Cornock, B. (2003) Sports participation and self-esteem: Variations as function of gender and gender role orientation- 1. Sex Roles, 49, 47 -58.

Furnham, A., Badmin, N., Sneade, I. (2002). Body image dissatisfaction: Gender differences in eating attitudes, self-esteem, and reasons for exercise. The Journal of Psychology, 136, 581-596.

Koivula, N. (1999). Sport participation: Differences in motivation and actual participation due to gender typing.
Journal of Sport Behavior, 22, 360-381.

Mann, M. M., Hosman, C. M. H., Schaalma, H. P., de Vries, N. K. (2004). Self-esteem in a broad-spectrum approach for mental health promotion. Health Education Research, 19, 357-372.

Marsh, H. W., Jackson, S. A. (1986). Multidimensional self-concepts, masculinity, and femininity as a function of women's involvement in athletics. Sex Roles, IS, $391-415$.

McCreary, D. R., Sasse, D. K. (2000). An exploration of the drive for muscularity in adolescent boys and girls. Journal of American College Health, 48, 297-304.

McCreary, D. R., Saucer, D. M., Courtenay, W. H. (2005). The drive for muscularity and masculinity: Testing the Associations among gender-role traits, behaviors, attitudes, and conflict. Psychology of Men and Masculinity, Vol. 6, 83-94.

Olivardia, R. (2002). Body image and muscularity. In T. F. Cash, T. Pruzinsky (Eds.), Body image: A Handbook of Theory, Research and Clinical Practice (pp. 210-218). New York, London: The Guilford Press. 
Pedersen, W., Wichstrom, L. (2001). Adolescents, doping agents, and drug use: A community study. Journal of Drug Issues, 31, 517-542.

Pope, Jr., H. G, Olivardia, R., Borowiecki, J. J., Cohane, G. H. (2001). The growing commercial value of the male body: A longitudinal survey of advertising in women's magazines. Psychotherapy and Psychosomatics, 70, 189-192.

Pope, Jr., H. G., Philips, K. A., Oliwardia, R. (2000). The Adonis Complex: The Secret Crisis of Male Body Obsession. New York: Free Press.

Puniskiene, R., Laskiene, S. (2006). Sportuojančių paauglių vertybinių orientacijų, asmenybès savybių ir savigarbos ypatumai. Sporto mokslas, 4, 48-54.

Raudenbush, B., Meyer, B. (2003). Muscular dissatisfaction and supplement use among male intercollegiate athletes. Journal of Sport and Exercise Psychology, 25,
$171-187$.

Richman, E. I., Shaffer, D. R. (2000). „If you let me play sports": How might sport participation influence the self-esteem of adolescent females? Psychology of Women Quarterly, 24, 189-199.

Robertson, S. (2003). "If I let a goal, I'll get beat up": contradictions in masculinity, sport and health. Health Educations Research, 18, 706-716.

Rosenberg, Morris (1989). Society and the Adolescent Self-Image. Revised edition. Middletown, CT: Wesleyan University Press.

Rosen, D. S. (2003). Eating disorders in adolescent males. Adolescent Medicine, 14, 677-689.

Sweeting, H., West, P. (2002). Gender differences in weight related concerns in early to late adolescence. Journal of Epidemiology and Community Health, 56, $700-701$.

\title{
PAAUGLIŲ BERNIUKŲ RAUMENINGUMO SIEKIMAS IR JO SĄSAJOS SU BENDRĄJA SAVIGARBA
}

\author{
Rasa Jankauskienė, Ramutis Kairaitis \\ Lietuvos kūno kultūros akademija, Kaunas, Lietuva
}

\section{SANTRAUKA}

Paauglių berniukų raumeningumo siekimas siejamas su prastesniu savęs vertinimu ir depresijos simptomais. Nustatyta, kad vyrai sportininkai yra labiau patenkinti savo kūnu negu nesportuojantys bendraamžiai, tačiau trūksta tyrimų, kurie atskleistų, kokios įvairias sporto šakas kultivuojančių berniukų raumeningumo siekimo ir jų bendrosios savigarbos sąsajos.

Buvo tiriama šimtas paaugliu berniukų (amžiaus vidurkis - 14,63 $\pm 1,97$ m.), iš jų 29 berniukai mokèsi šeštoje klasejje, 34 - aštuntoje ir 37 - dešimtoje. Jie užpilde klausimyną, sudarytą iš tokiu klausimų blokų: klausimai, nusakantys demografinius kintamuosius (amžių, klasę, gyvenamają vietą (miestą arba kaimą), atskleidžiantys bendrają savigarbą (Rozenberg, 1989), pasitenkinimą savo išvaizda, savo kūno daliu vertinimą, dalyvavimą popietinèje veikloje. Dalyvaujančiais popietinèje veikloje buvo laikomi tie moksleiviai, kurie ne mažiau kaip pusę metų lankè ir formaliai priklausè būreliui, popietinio lavinimo mokyklai, klubui, o ne užsiiminėjo veikla savarankiškai. Papildomai moksleiviai užpildè raumeningumo siekimo klausimyną (McCreary, Sasse, 2000).

Rezultatai atskleidè, kad nèra statistiškai reikšmingo skirtumo tarp ịvairia popietine veikla užsiimančių berniukų polinkio siekti raumeningumo, nors daugiausia raumeningumo siekia šokius lankantys berniukai. Sportuojantys ir nesportuojantys paaugliai statistiškai reikšmingai nesiskyre savigarba ir išvaizdos vertinimu, nors išvaizdą geriausiai vertino šokius lankantys berniukai. Ivairia popietine veikla užsiimančių berniukų, tarp jų ir sportuojančių, raumeningumo siekimas nebuvo statistiškai reikšmingai susijęs su prastesniu išvaizdos vertinimu ir bendra savigarba. Rezultatai gali būti paaiškinami šitaip: sportavimas keičia negatyvų raumeningumo siekimo požiūrị, taip pat jis gali būti susijęs su siekimu atitikti sporto šakos reikalavimus, bet ne tam tikro išvaizdos siekimo standarto. Nepasitenkinimas savo kūno išvaizda, svoriu yra dažniau susijęs su prastesne savigarba tarp mergaičiu, o ne tarp berniukų. Atliktas tyrimas iš dalies patvirtina šiuos duomenis. Tolesni tyrimai turètų būti orientuoti tirti raumeningumo siekimo, savo kūno vertinimo ir savigarbos ryšius tarp berniukų, užsiimančių rekreaciniu ir pasiekimų sportu.

Raktažodžiai: raumeningumo siekimas, savigarba, popietinès pratybos.

Gauta 2007 m. gegužès 16 d.

Received on May 16, 207

Priimta $2007 \mathrm{~m}$. rugsèjo $19 \mathrm{~d}$.

Accepted on September 19, 2007
Rasa Jankauskienè

Lithuanian Academy of Physical Education

(Lietuvos kūno kultūros akademija)

Sporto str. 6, LT-44221 Kaunas

Lithuania (Lietuva)

Tel +370 37302664

E-mail r.jankauskiene@lkka.lt 